\title{
Desalination and water security in Southeastern Spain
}

\author{
Miguel Borja Bernabé-Crespo ${ }^{1}$ \\ Encarnación Gil-Meseguer \\ José M. Gómez-Espín \\ University of Murcia, Spain
}

\begin{abstract}
The Segura Hydrographic Demarcation (DHS), in Southeastern Spain, is an area of hydric deficit caused by low and irregular rainfall and a dense population. In this region water scarcity is a burning issue that polarizes society for or against different models of ensuring water supply. Given the current demand for water throughout Spain, desalination has been used to increase water supply, and as insurance against drought. Ten seawater desalination plants and hundreds of brackish aquifer desalination plants treat water in the Southeast of the Iberian Peninsula, both for human consumption and for irrigation, contributing to economic, energetic, processual and economic aspects of territorial organization in the Southeast of Spain. This article reviews debates over desalination, water transfers, and the best way to meet water demands in that region. While desalination allows an increase in water supply, dependence on that source increases energy costs and may lead to mistaken assumptions among users about water scarcity and availability.
\end{abstract}

Keywords: seawater desalination, brackish aquifer desalination, human water supply, social debate, irrigation, Southeast of Spain

\section{Resumé}

La Démarcation Hydrographique du Segura (DHS) comprend une zone déficitaire hydrique occasionnée par une pluviométrie faible et irrégulière et une occupation intense du territoire, où l'eau a été et reste encore un bien limité et très précieux depuis l'Antiquité. C'est un problème brûlant qui polarise la société pour ou contre un modèle ou un autre de l'offre d'eau. Compte tenu des demandes actuelles de cette ressource, il est nécessaire d'avoir recours au dessalement pour une augmentation de l'approvisionnement en eau qui constitue une assurance contre les situations de sécheresse en Espagne. Dix usines de dessalement d'eau de mer et des centaines de stations de dessalement d'eau d'aquifères salins fournissent de l'eau dessalée le sud-est de la Péninsule Ibérique, pour la consommation humaine et pour l'irrigation des champs fertiles, contribuant à leur idiosyncrasie économique, énergétique, processuelle, économique et d'organisation territoriale.

Mots clé: dessalement de l'eau de mer, dessalement des aquifères saumâtres, approvisionnement en eau humaine, débat social, irrigation, sud-est de l'Espagne

\section{Resumen}

La Demarcación Hidrográfica del Segura (DHS) comprende un área hídricamente deficitaria motivada por una reducida e irregular pluviometría y una intensa ocupación del territorio, en la que el recurso agua ha sido y es un bien limitado y muy preciado desde la antigüedad, y es un candente asunto de la actualidad que polariza a la sociedad a favor o en contra de un modelo u otro de abastecimiento. Ante las actuales demandas de este recurso, se hace necesario recurrir a la desalación para un incremento de la oferta hídrica que actúa como un seguro ante situaciones de sequía en España. Un total de diez plantas desaladoras y cientos de desalobradoras suministran agua desalada procedente del mar o de acuíferos salobres en el Sureste de la Península Ibérica, tanto para

\footnotetext{
${ }^{1}$ Miguel Borja Bernabé-Crespo, Predoctoral fellow (Ministry of Education, Culture and Sports of Spain), Department of Geography, University of Murcia, Spain and Research Visiting Scholar at University of California Santa Barbara, USA. Email: miguelborja.bernabe@um.es. Dr. Encarnación Gil-Meseguer and Dr. José María Gómez-Espín, Professors, Department of Geography, University of Murcia, Spain. We thank Prof. Casey Walsh and two anonymous reviewers for editorial comments.
} 
consumo humano como para la irrigación de los fértiles campos, aportando su idiosincrasia económica, energética, procesual y de ordenación territorial.

Palabras clave: Desalación, desalobración, abastecimiento humano, debate social, irrigación, Sureste de España

\section{Introduction}

Southeastern Spain is a region of the Iberian Peninsula located on the Mediterranean coastline from Cape de la Nao to Cape Gata. Its inland boundaries are defined by the isotherm of $16{ }^{\circ} \mathrm{C}$ average annual temperature and an isohyet of less than $400 \mathrm{~mm}$ of annual rainfall. It is an arid land, because of its position on the leeward side of the Betic mountains, which run northeast to southwest generating a foehn effect and act as an orographic shelter (Figure 1). This climatic region corresponds to the litoral and pre-coastal regions of Murcia, Almeria and the southern half of Alicante with an approximate area of more than $20,000 \mathrm{~km}^{2}$. In this semi-arid area of Mediterranean, seasonal rivers and streams - known as ramblas - remain dry most of the year, with a very limited flow except for occasional surface run-off and flash floods. Allochthonous rivers such as the Segura, which receives rainfall from headwaters located outside this climatic region, have been the main sources of water supply over centuries.

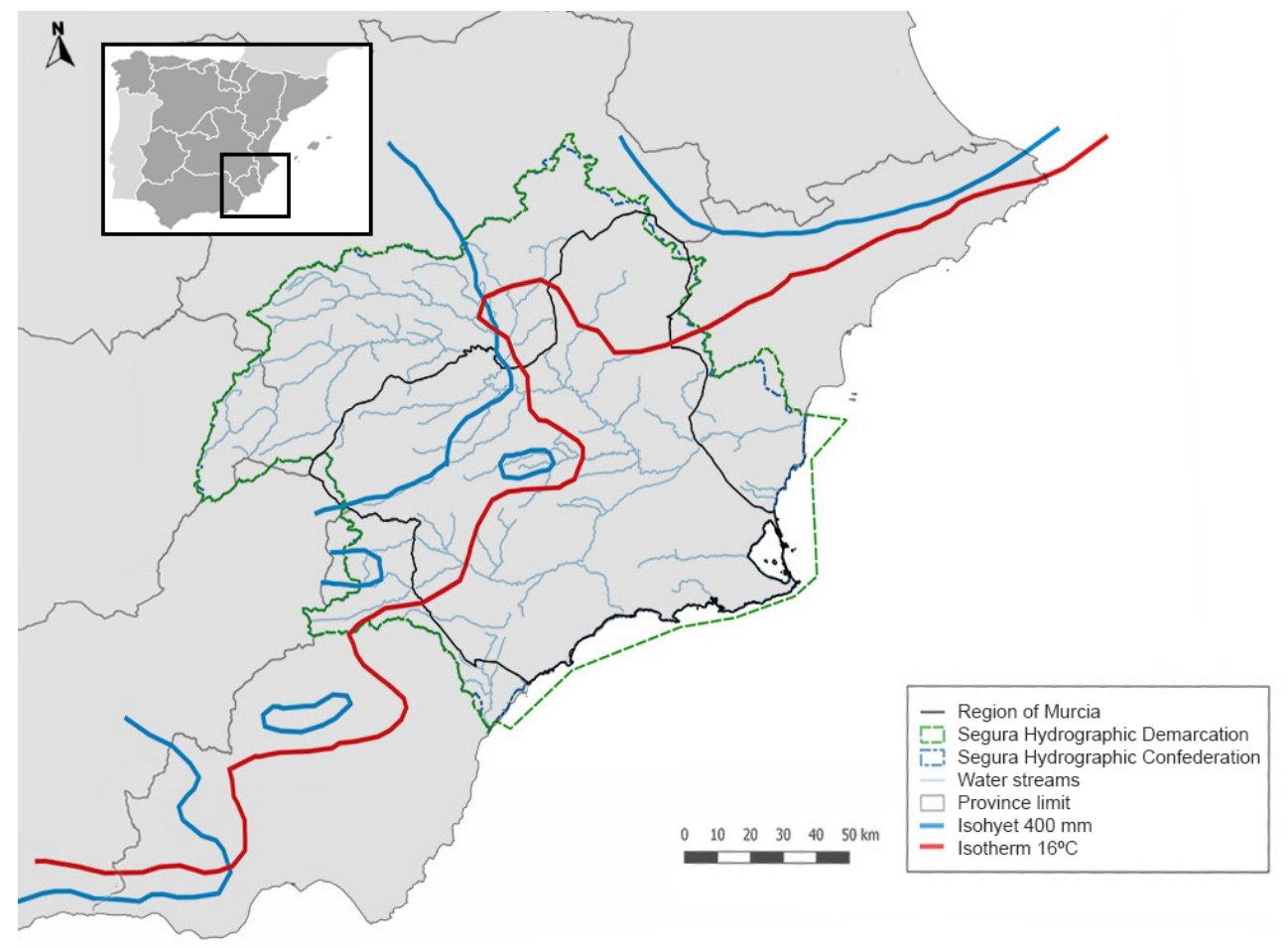

Figure 1: Area of study

Due to the scarcity of rainfall and surface water, historically water was captured in aljibes (cisterns) and produced with qanats (Gil and Gómez 1993), which are vertical 'chain' wells that capture groundwater in a subterranean channel. In the last century water has been supplied by transfers of water from other rivers (Bernabé and Gómez 2015; Gil 2017). Since the 1950s, for example, water has been transferred from the Taibilla River in Albacete through a network of channels to the provinces of Murcia and Alicante, and the 'Commonwealth of Canals of Taibilla' (MCT) agency has supplied water to the majority of municipalities in the Segura River Basin (Figure 2). In 1979, more expansive infrastructure enabled water transfers from the 
Tagus River, which flows west through Spain and Portugal. However, with the recent failure of even grander plans to receive transfers from the Ebro River in the far north of Spain, desalination has emerged as a way to satisfy the demands of a growing population in the region, and to support agriculture and tourism as the economic base of the Southeast.

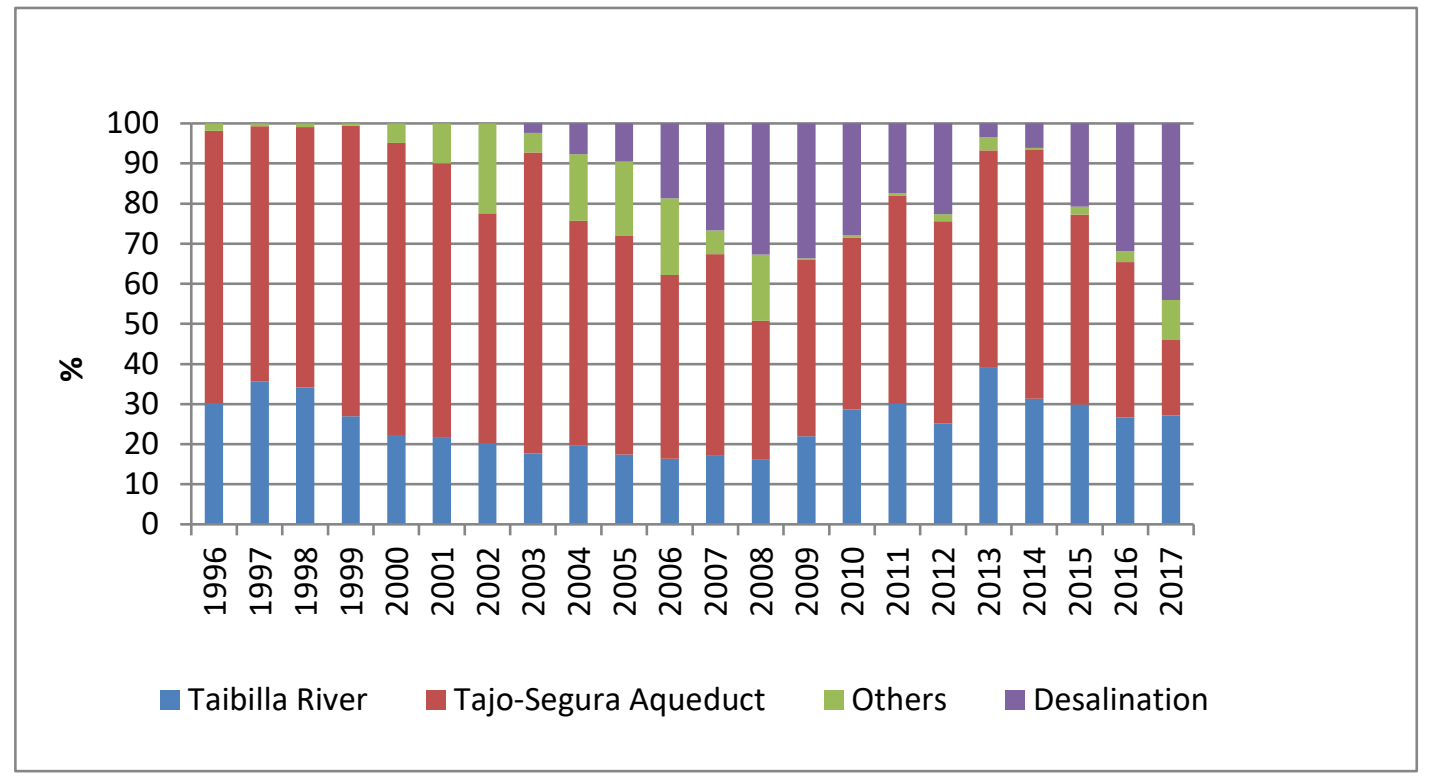

Figure 2: Different water resources for MCT supply (1996-2017). Source: MCT.

The limitless availability of seawater in the Southeast makes desalination plants strategic tools for producing an "unconventional" freshwater resource that, due to its growing prominence, has become "conventional" (Rico et al. 1998). Given the flow variations in the Taibilla River and the progressive decreases in the water transferred from the Tagus River, the volume of desalinated water has increased steadily since the first plant was commissioned in 2003 in Alicante, reaching 32\% of the total water supplied in 2016, and close to $50 \%$ in 2017 , when the Tajo-Segura transfer was shut down for months. About $25 \%$ of the population of large cities in the Southeast suffer water stress, but very rarely (only about $2 \%$ ) do these city dwellers depend on water from desalination. Rather, 75\% of urban population depends on surface water (McDonald et al. 2014: 100). Desalination in the Southeast of Spain thus has the role of providing "water security" in the face of general water insecurity. It can increase socioeconomic stability or, on the contrary, lessen it if environmental factors or vulnerability and dependency are taken into account. The Intergovernmental Panel on Climate Change refers to desalination as an adaptive option to climate change (Bates et al. 2008: 49), but we must recognize the risk of a "maladaptation" if vulnerability is increased by dependence on the resource (McEvoy and Wilder 2012: 359).

This article explains the role of seawater and brackish aquifer desalination for the different water uses in the Southeast of Spain. It assesses whether the quantities provided are sufficient for domestic uses in situations of drought, and whether they thus are a solution to "water insecurity." Finally, the article evaluates whether the expansion of desalination to meet the demands of irrigation is sustainable. Methodologically, it is a geographical study of a region where the lack of water is structural and very severe in situations of drought. Chronologically, the article covers the period between 1979, when the waters of the Tagus-Segura Transfer arrived, and 2017, when a drought in Spain and especially in the Southeast resulted in the elimination, for the first time, of water transfers. Along with comparative bibliographic analysis of desalination in other dry regions of the globe, extensive fieldwork was conducted on all the desalination plants in the Southeast of the Iberian 
Peninsula. Interviews were conducted with the users of these waters, with the managers of the Commonwealth of Taibilla Channels (MCT), and with several Irrigation Communities.

\section{A political ecology approach}

Described as "hatchet and a seed" by Robbins (2012), political ecology focuses on environmental issues in order to dismantle unfair practices and behavior, while proposing alternative ways of thinking and acting to achieve adequate environmental management and social justice. There can be more than one option for more sustainable development: each action or project, if coordinated with an exhaustive local investigation, can bring locally appropriate development in the face of climatic and geopolitical threats. The seed of political ecology must be planted by local efforts of an autonomous character that are committed to environmental actions (Cavanagh and Benjaminsen 2017: 203).

Water use is a major theme in political ecology, which often focuses on power and justice in management decisions over water (Radonic and Kelly-Richards 2015). Aggressive and neglectful environmental policies can undermine socioeconomic development of a region, as happened in the oasis of Khorezm (Brite 2016), in present-day Uzbekistan, with the reduction of the Aral Sea. Interactions among human activity and the physical and social environment related to water flows define hydrosocial territories (Ženko and Uležić 2019). Territorial management can be inclusive or exclusionary because of the different aspirations and values of different, usually unequal, social groups (Boelens et al. 2016). Other research shows the importance of culture in demand management (Walsh 2011). As Walsh (2018: 161) states, "water defines social groups and their boundaries" and everyday interactions with water are an important key to understand its social value. In the semi-arid region of Southeastern Spain there is an ancient tradition of water use and management that enables people to face chronic scarcity and droughts through efficient use and just distribution (Bernabé-Crespo and Gómez-Espín 2015; Gómez-Espín 2004). These water practices and values have formed a deep culture in the region, as evidenced by the sacred processions to pray for rain (rogativas), or the reputation for social and health values that mineral baths have throughout this region.

On the other hand, national water strategies adopted in the twentieth century made possible the delivery of new waters transferred from the Tagus River, provoking an extraordinary level of socioeconomic development, and relief for a society lacking water even for human consumption (Swyngedouw 2015). A syndicate of irrigators from Tagus-Segura has learned to depend on this source and campaigns for the maintenance of this source of water, arguing that it boosts the economy and increases water security in this region (Gómez-Espín 2017). But water a source of constant conflict. As noted by Swyngedouw (2004), scales of water management vary and are constantly redefined, and conflicts differ according to the actors involved (such as users, or politicians). Caldera (2017) reports that conflicts over water use are rising in Mexico (irrigators vs. industry vs. urban consumption), and imbalances in water allocation are seen to benefit those with economic and political power. Despite these conflicts across scales and hierarchies, local irrigator organisations are able to manage water in a sustainable way through water exchanges, water storage, water saving technologies, and other measures (Palerm and Martínez 2000).

Desalination is seen by many as the solution to water scarcity. Elsewhere, up to fifteen desalination plants have been proposed for California's southern and central coast, making that state home to the highest number of seawater desalination plants in the USA (Heck et al. 2016: 179), although only one of them is currently operating. Also important are projects for brackish desalination in Texas, for example in Alamogordo (Chowdhury et al. 2013: 63). The benefits of desalination can cross borders and binational relationships, as in the case of the desalination plant in the desert beach town of Puerto Peñasco (Mexico) built to supply Arizona and Nevada (McEvoy and Wilder 2012: 357). In Australia, desalination is also considered an adaptation to climate change and regarded as a source of secure supply. The clear intention is to reduce dependence on rainfed supplies that are vulnerable to drought and climate change, although a large plant in Victoria has yet to be fully deployed due to greater precipitation since the mid 2000s when it was built (Rutherfurd and Finlayson 2011: 311). In Abu Dhabi, 30\% of the water supply is desalinated seawater, used predominantly for drinking (McDonnell 2014: 225). In short, water scarcity is a matter of acute general interest worldwide and polarized 
positions have formed concerning the appropriate management response: either to expand (or maintain, at least) transfers into deficit regions, or to reduce or replace them with desalination (Swyngedouw 2013).

\section{Ecosocial water policy in Spain}

In Spain there is currently a conflict between those who advocate for water transfers and those who argue for desalination. Desalination stands as the alternative proposed by anti-transfer politicians, despite the higher price and lower quality of desalinated water. Water management in that country is organized at the scale of river basins. This supra-provincial territorial organization takes the hydrographic basin as a reference, and there have been successes in the management of water resources at this scale. Despite the fact that it overlaps with other administrative boundaries, the river basin approach reflects natural connections that determine water quality and quantity. However the natural limits of the river basin can be modified by hydraulic works, so these river basin territories are in constant flux (Del Moral and Hernández-Mora 2016).

Hydraulic policy in the autonomous communities (comunidades autónomas) established by the Constitution of 1978 guarantees limited autonomy and some devolved powers to nationalities and regions. Who should appropriate of surface waters is debated, with some in the regions arguing for local control. An extreme expression of this position is that water simply belongs to the one who is next to the river, so they can appropriate all the resource that they need. An opposing position is that water is a public good, and the State should administer and deliver the water to users through concessions. This debate transcends scales in water policy and spatial planning, and reveals the social nature of water itself.

This debate has intensified since 2001, when the Popular Party government approved the National Hydrological Plan (NHP). In 2004 the Socialist government corrected the NHP, eliminating the plan to transfer water from the Ebro river to the Mediterranean basins of Júcar, Segura and Almanzora (Arrojo 2000: 43). Arguments raged in the media about whether water is a good for all Spaniards and if spatial imbalances in water availability must be corrected to ensure water security and sustainability for citizens in dry regions such as the Southeast. Campaigns were launched to mobilize society, with mottos like "Water for everyone" and "Water unites us" opposing "They steal our water" or "Water for golf" (the latter a response to the rise of tourist resorts in the Southeast).

Instead of the Ebro scheme the Socialist government proposed its AGUA plan, which planned the construction of desalination plants on the Mediterranean coast as the means to deal with the water crisis in the drylands. It was expected that the price of desalinated water would range between $60-90$ pesetas (US\$0.4-0.6) $/ \mathrm{m}^{3}$ while transferred water would cost only 30 pesetas (US\$0.2) $/ \mathrm{m}^{3}$ (Arrojo 2000: 51). Desalination was opposed by some who preferred a model of cheaper, better-quality water provided by transfers, with high productivity amortizing infrastructure costs. The high cost of desalination is countered by the argument that seawater is an unlimited resource whereas the 'giving' watershed would lose water in a transfer. This position is gaining sway, and in June 2018 the new Spanish Government commited to using desalination in the water supply for the Southeast. The Government has even questioned the existing Tagus-Segura transfer, citing public opposition to "structural deficits" and "negative balance watersheds", moving forward with a policy of reducing water demand through pricing mechanisms. The question remains whether desalination will be sufficient to avoid water scarcity in Spain's arid Southeastern regions or if it should be a complementary source of supply, along with water transfers, groundwater pumping and recycled wastewater (Gil-Meseguer et al. 2017: 2480).

The high cost of desalination is an important issue. Spain is energetically deficient - it has to import energy from other countries - and desalination, using the reverse osmosis process, consumes a large amount of electricity, which is one reason the production of desalinated water is more expensive compared to the other sources. Another economic issue is the cost of building and maintaining desalination plants, which must be kept in working order even during non-drought periods when their operation, and revenue, is much lower than capacity. It must be remembered that the profitability of desalination plants is not constant but rather varies in relation to supply and demand. Decades ago desalinated waters "were only profitable for industry" (Montaner 1994: 215), but now this is also true for agriculture, as "certain crops can cope with the high costs of desalination 
due to their high profitability. This is possible either by accepting a reduction in the profit margin or as the only alternative to survival in situations of extreme lack of resources" (Montaner 1994: 215). Currently, although desalinated water is considerably more expensive than other types of water, its use has been extended to human consumption as well as for irrigation of all types of crops.

The plan to expand desalination in Southeast Spain is based on the idea that it will drive socioeconomic development that will help to recover costs. In recent years desalination has contributed water that could not have been provided by another source, due to droughts and the unfavorable political climate for water transfers. The installation of desalination plants establishes the ability to supply huge volumes of water for irrigation and urban use, supporting both agriculture and a successful tourism industry. The expansion of tourism in the summer months in the Southeast, which is the season of less rainfall and higher water consumption in the semiarid Mediterranean climate, suggests that desalination has produced a steady and increasing water supply. Since the installation of desalination plants on Spain's Canary Islands, for example, more than 71,000 hotel and non-hotel units have been created in Lanzarote, and 67,000 in Fuerteventura (García-Rodríguez 2016: 124). Desalination provides certainty for the tourism sector.

Finally, there are important issues about the quality of desalinated seawater. Although it is adequate for both human consumption and irrigation, the presence of boron must be maintained between the limits established by the European Directive 98/83/EC and assumed by Spain in Royal Decree 140/2003 to avoid harmful effects ( $1 \mathrm{mg} / \mathrm{L}$ for human consumption, $0.5 \mathrm{mg} / \mathrm{L}$ for irrigation). Agriculture, less tolerant to boron, cannot depend solely and exclusively on desalinated water, because crops (especially citrus) suffer from a high concentration of this element. To cover agrarian needs, different waters must be mixed so as to control mineral concentrations.

\section{Desalinated water production in Southeast Spain}

As early as 1994, Torres (1994: 121) reported that "the Spanish experience in desalination is one of the most positive that can be found in the world." In the eastern Canary Islands chronic shortages in the system of Navy water tanks were overcome by the production of desalinated water (García-Rodríguez et al. 2016: 123), something that also happened in Benidorm (Southeast of Spain) in 1978. But in the Southeast of the country, despite the installed capacity of desalination plants and the implementation of water saving measures to reduce demand, the water produced by desalination has been insufficient to meet needs in some periods of drought and scarcity. Proof of this shortfall is the eagerness of farmers to enter into agreements with desalination plants, the investments made by the Irrigator Communities in building their own desalination plants, and the plans for expanding capacity in the existing ones. Certain Communities of Irrigators depend almost exclusively on these flows of desalinated waters. Likewise, it is a cornerstone of supply for the MCT, whose plants are producing at full capacity.

In 2017, a severe drought in the Southeast and in the headwaters of the Tagus and Guadalquivir Rivers caused the closure of the Tagus-Segura Transfer in May and the Negratin-Almanzora Transfer in September. Less than a third of the average rainfall fell in the region: reservoirs were at barely $13 \%$ of capacity with about fifteen million cubic meters (12,160 acre-feet). In addition to the usual 130 million $\mathrm{m}^{3} /$ year (105,393 acre-feet) of recycled water from sewage, many new wells were perforated with the result being an unsustainable overexploitation of aquifers. The drought also accelerated a turn to desalination as a source of new water. 


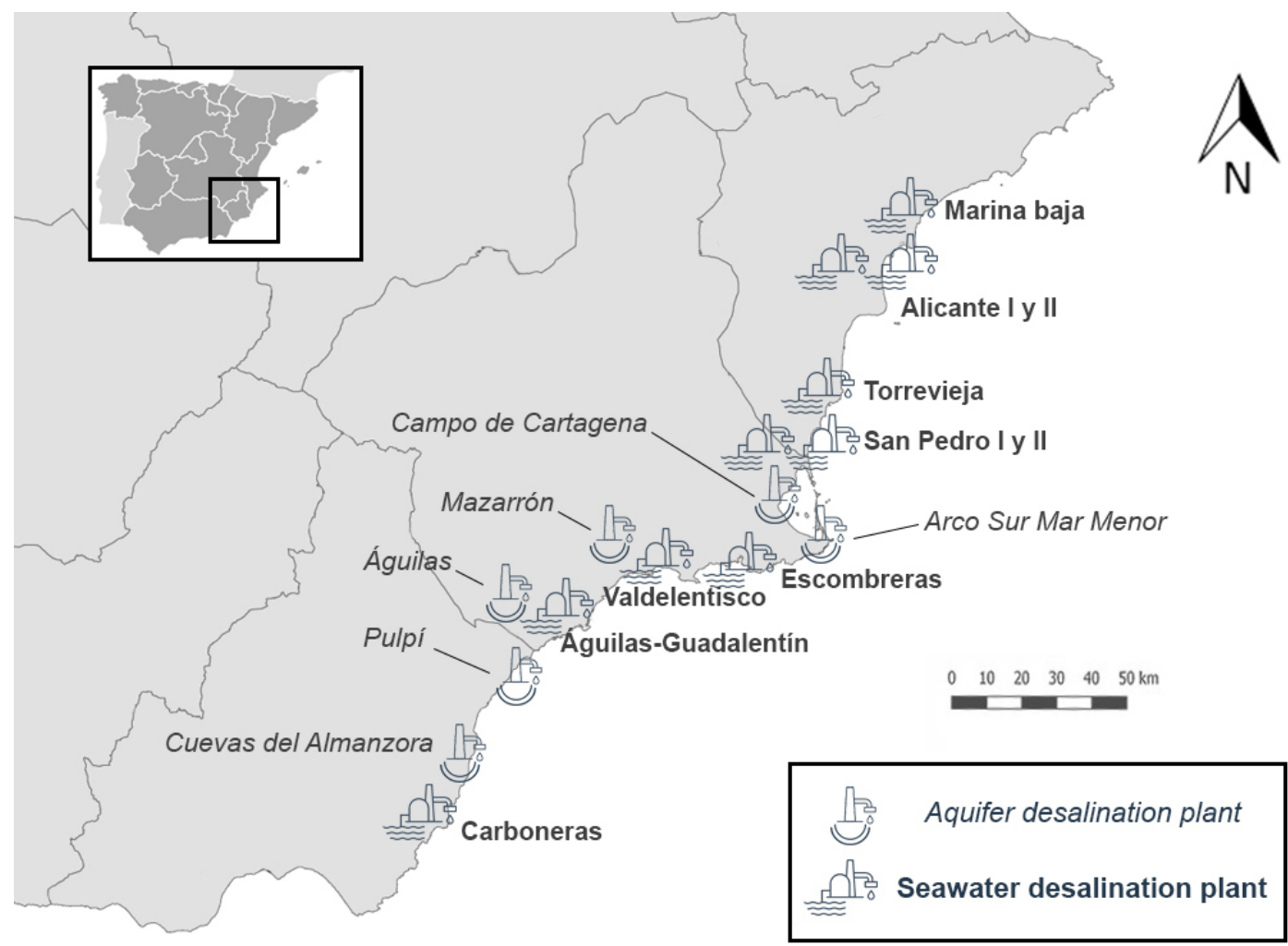

Figure 3: Map of desalination plants in the Southeast of Spain. Source: authors.

\section{Seawater desalination}

By January 2018, the Southeast had a total of ten seawater desalination plants (Figure 3), with a combined treatment capacity of more than 1,000,000 $\mathrm{m}^{3} /$ day for irrigation and human consumption (Table 1). The largest installed capacity is at Torrevieja $\left(240,000 \mathrm{~m}^{3} /\right.$ day), although due to shortage of electricity at that site, the plant that produces more desalinated water is Águilas-Guadalentín (close to 180,000 $\mathrm{m}^{3} /$ day). The MCT has four plants (San Pedro I and II, Alicante I and II) entirely for domestic supply, which together produce $260,000 \mathrm{~m}^{3} /$ day. In addition, the MCT has contracted other volumes with the Águilas-Guadalentín plant (1 million $\mathrm{m}^{3}$ /year, 810.7 acre-feet), Valdelentisco plant (13 million m³/year, 10,539 acre-feet) and the Torrevieja plant (variable). Other desalination plants operated almost exclusively for irrigation, such as Escombreras, but in the second half of 2017 all the plants (including those of Escombreras and Valdelentisco) were prioritized for human supply and domestic use. In most plants, seawater is pumped to the plant, although in others, like Carboneras, this energy is saved by using reservoirs built at the same level so that water moves with minimal energetic cost due to the proximity of the desalination plant to the sea and its elevation (6 meters above sea level). 


\begin{tabular}{|c|c|c|}
\hline Desalination plant & Treatment capacity (m³/day) & $\begin{array}{c}\text { Destination of produced water in } 2016 \\
(\%)\end{array}$ \\
\hline Marina Baja & 50,000 & $100 \%$ Urban \\
\hline Alicante I & 65,000 & $100 \%$ Urban \\
\hline Alicante II & 65,000 & $100 \%$ Urban \\
\hline Torrevieja & 240,000 & 90\% Irrigation $10 \%$ Urban \\
\hline San Pedro I & 65,000 & $100 \%$ Urban \\
\hline San Pedro II & 65,000 & $100 \%$ Urban \\
\hline Escombreras & 63,000 & $100 \%$ Irrigation \\
\hline Valdelentisco & 137,000 & $62 \%$ Irrigation $38 \%$ Urban \\
\hline Águilas-Guadalentín & 180,000 & 98\% Irrigation 2\% Urban \\
\hline Carboneras & 120,000 & 53\% Irrigation $47 \%$ Urban \\
\hline TOTAL & $1,050,000$ & \\
\hline
\end{tabular}

Table 1: Treatment capacity and destination of the water produced in the desalination plants of the Southeast. Source: authors, based on interviews with plant managers (2016).

The technology used in all plants is reverse osmosis (RO), whose conversion factor (from seawater to desalinated water) is between 42 and 46\%. The energy consumed by these desalination plants is around 3 to 4 $\mathrm{kW} / \mathrm{m}^{3}$, but in Valdelentisco it is 3.1 to $3.8 \mathrm{~kW} / \mathrm{m}^{3}$ (or even less if energy recovery processes are applied) and in Carboneras it was lowered from 4.2 to $2.5 \mathrm{~kW} / \mathrm{m}^{3}$ between 2014 to 2017. By comparison, energy consumption is around $3 \mathrm{kWh}$ per $\mathrm{m}^{3}$ in the reverse osmosis plants in the Canary Islands (Baltanás, 2013). This contrasts with older technologies such as MSF (sudden evaporation stage), which expends $3.6 \mathrm{~kg}$ of fuel per $\mathrm{m}^{3}$, or MED (multi-effect evaporation) with $3.2 \mathrm{~kg}$ of fuel per $\mathrm{m}^{3}$. These two techniques are only applicable to seawater, while RO is applicable to both seawater $\left(1.3 \mathrm{~kg}\right.$ of fuel per $\left.\mathrm{m}^{3}\right)$ and brackish water $\left(0.4 \mathrm{~kg}\right.$ of fuel per $\left.\mathrm{m}^{3}\right)$ (Torres 1994: 112). At present, plants operate at almost maximum yield, with the exception of Torrevieja which is awaiting another electricity substation (it only produces $130,000 \mathrm{~m}^{3} /$ day), and Valdelentisco, which has not yet reached its maximum capacity (34 million $\mathrm{m}^{3} /$ year to 46 million $\mathrm{m}^{3} /$ year, or 37,293 acre-feet).

Environmental concerns have not hindered desalination efforts in Southeastern Spain. The brine discharge (water with a higher salt concentration) is carried out to sea and diluted through diffusers to make it less noticeable and to minimize adverse environmental impacts. In California, by comparison, concerns about loss of biodiversity due to water intake and brine discharges, and changes to water quality and marine habitats, have been a major impediment to the development of desalination. In some cases in Spain desalination can even be seen to have paradoxical positive environmental impacts. In Valdelentisco the discharge occurs at the mouth of the rambla and has created an area where, due to the installation of diffusers, the fishing vessels cannot fish, thus, creating a kind of 'marine reserve.' And in Carboneras, the spillage of brine serves to cool the effluent of the Carboneras Thermal Power Plant. If conservation measures are complied with, desalination can also reduce the pressure on aquifers and make more water available for the natural environment (McEvoy and Wilder 2012: 359).

Desalination can also reduce the use of water transfers. In recent years, flows discharged into the TagusSegura Aqueduct have decreased while the production of desalinated water has increased, both for human and agricultural use. Table 2 shows the production of desalinated water in the MCT plants, entirely for human consumption, and in Table 3 the production of the Carboneras plant, specifying its use. The data show a constant increase in desalinated water: MCT has increased its production exponentially, while in Carboneras it has increased fivefold in the last five years. 


\begin{tabular}{|r|r|r|r|r|r|}
\hline Year & San Pedro I & \multicolumn{1}{c|}{ San Pedro II } & \multicolumn{1}{c|}{ Alicante I } & Alicante II & TOTAL ( $\left.^{\mathbf{3}}\right)$ \\
\hline 2014 & $5,043,490$ & $2,344,600$ & $2,785,750$ & $1,051,900$ & $\mathbf{1 1 , 2 2 5 , 7 4 0}$ \\
\hline 2015 & $23,208,100$ & $5,026,500$ & $7,472,650$ & $2,854,900$ & $\mathbf{3 8 , 5 6 2 , 1 5 0}$ \\
\hline 2016 & $22,919,930$ & $2,344,600$ & $10,250,368$ & $7,510,770$ & $\mathbf{4 3 , 0 2 5 , 6 6 8}$ \\
\hline 2017 & $22,727,100$ & $17,241,900$ & $12,345,722$ & $9,824,700$ & $\mathbf{6 2 , 1 3 9 , 4 2 2}$ \\
\hline
\end{tabular}

Table 2: Production of MCT desalination plants $\left(\mathrm{m}^{3}\right)$ in the last three years (2014-2017). Source: authors, data from MCT (2018).

Analyzing the production data by months, there is a greater production of desalinated water in summer and autumn, almost reaching production capacity. Concomitantly, due to the paralysis of transfers from TajoSegura, it has become necessary to acquire larger volumes from other desalination plants for irrigation (Figure 4). For MCT, the production peak occurs in August, followed by July, September and June, in this order. This coincides with the increase in tourism during summer, and greater consumption of water due to increased temperatures and leisure uses.

\begin{tabular}{|c|c|c|c|c|c|c|c|}
\hline \multirow{2}{*}{ Year } & \multicolumn{2}{|c|}{ Human Consumption } & \multicolumn{2}{|c|}{ Irrigation } & \multicolumn{2}{|c|}{ Other Uses } & \multirow{2}{*}{$\begin{array}{c}\text { Total } \\
\text { Desalinated } \\
\text { Water }\left(\mathbf{m}^{3}\right)\end{array}$} \\
\hline & $\mathrm{m}^{3}$ & $\%$ & $\mathrm{~m}^{3}$ & $\%$ & $\mathrm{~m}^{3}$ & $\%$ & \\
\hline 2005 & $1,738,506$ & 70.46 & 526,638 & 21.34 & 202,329 & 8.20 & $2,467,473$ \\
\hline 2006 & 2,883,378 & 52.95 & $2.271,557$ & 41.72 & 290,196 & 5.33 & $5,445,131$ \\
\hline 2007 & $3,171,892$ & 54.26 & $2.424,098$ & 41.47 & 249,228 & 4.26 & $5,845,218$ \\
\hline 2008 & $2,829,590$ & 42.66 & $3.496,289$ & 52.71 & 307,503 & 4.64 & $6,633,382$ \\
\hline 2009 & $2,548,909$ & 35.29 & $4.301,501$ & 59.56 & 371,659 & 5.15 & $7,222,069$ \\
\hline 2010 & $2,562,258$ & 42.45 & $2.972,679$ & 49.26 & 500,337 & 8.29 & $6,035,274$ \\
\hline 2011 & $2,127,307$ & 33.94 & $3.613,901$ & 57.65 & 527,283 & 8.41 & $6,268,491$ \\
\hline 2012 & 2,369,553 & 24.82 & $6.613,571$ & 69.27 & 564,105 & 5.91 & $9,547,229$ \\
\hline 2013 & $6,073,414$ & 50.01 & $5.579,320$ & 45.95 & 490,527 & 4.04 & $12,143,261$ \\
\hline 2014 & $8,457,421$ & 51.60 & $7.427,738$ & 45.32 & 504,085 & 3.08 & $16,389,244$ \\
\hline 2015 & $14,568,429$ & 57.61 & $10.268,354$ & 40.61 & 449,877 & 1.78 & $25,286,660$ \\
\hline 2016 & $15,436,265$ & 46.66 & $17.147,661$ & 51.84 & 495,129 & 1.50 & $33,079,055$ \\
\hline
\end{tabular}

Table 3: Production of desalinated water and its use in Carboneras (Almería). Source: authors, data from Acuamed (2017). 


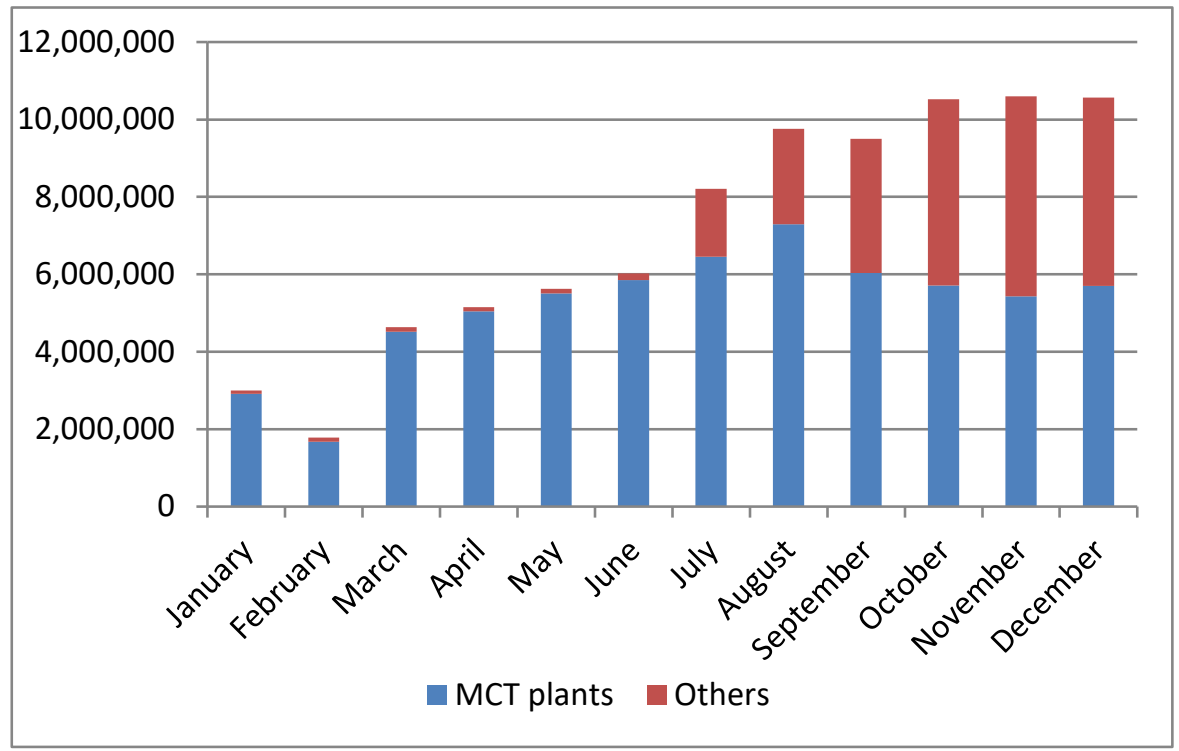

Figure 4. Origin of desalinated water for MCT by months $\left(\mathrm{m}^{3}\right)$. Source: authors.

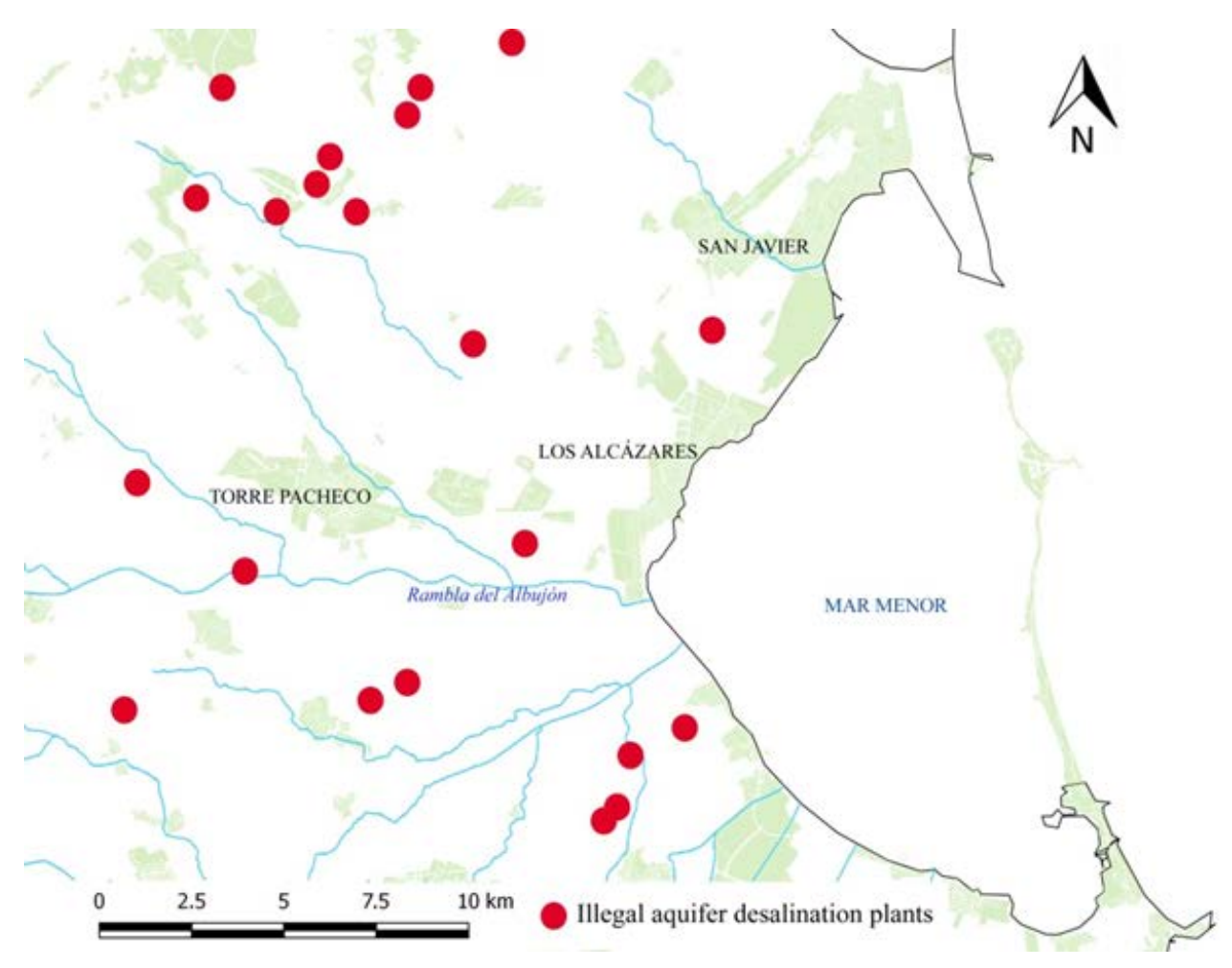

Figure 5: Small brackish aquifer desalination plants in the Cartagena-Mar Menor area. Source: La Verdad newspaper, 15/12/2017 and authors, data from MCT (2018). 


\section{Brackish aquifer desalination}

Less expensive than seawater desalination, is the desalination of brackish aquifers and surface run-off. This cheaper solution tends to be more successful in areas far from the coast, with scarce surface water and salinized aquifers. The analysis of water sources for desalination shows that about $55 \%$ of desalination plants in the US use brackish water and are located in the interior of the country (Ziolkowska and Reyes 2016: 120).

Irrigation needs led individual users and several irrigation communities to build aquifer desalination plants in Southeast Spain (Figure 5). The process used in these plants is, like the seawater plants, reverse osmosis, except that a powerful filtering system is unnecessary, which lowers costs. Remineralization of the water is also not necessary, since the destination is irrigation. The Community of Irrigators of Mazarrón owns the Virgen del Milagro plant, with a capacity of 40,000 $\mathrm{m}^{3} /$ day, which takes water from thirteen wells. This Irrigation Community depends totally on the recycled and desalinated water from Mazarrón Sewage Treatment Plant (STP). The Arco Sur Irrigation Community uses a similar plant, with a production of 28,000 $\mathrm{m}^{3} / \mathrm{day}$, to take advantage of its allocation of the recycled flow from Mar Menor STP, as well as water from wells and subsurface runoff drains. In 2016, 78\% of the water used by Arco Sur came from Mar Menor STP, 17\% from drains, and 5\% from wells of the Campo de Cartagena. The plant located in El Mojon, which belongs to the Irrigation Community of Campo de Cartagena, also collects surface runoff by means of drainages and desalinates it with three RO racks that each process $210 \mathrm{~m}^{3}$ of water per hour.

\begin{tabular}{|c|c|c|}
\hline Year & $\begin{array}{c}\text { Treated water } \\
\mathbf{( m}^{\mathbf{3}} \mathbf{)}\end{array}$ & $\begin{array}{c}\text { Produced water (for } \\
\text { irrigation, } \mathbf{~}^{\mathbf{3}} \mathbf{)}\end{array}$ \\
\hline 2008 & $1,002,550$ & 751,876 \\
\hline 2009 & $1,596,400$ & $1,197,311$ \\
\hline 2010 & $2,582,765$ & $1,937,049$ \\
\hline 2011 & $3,932,105$ & $2,046,826$ \\
\hline 2012 & $3,432,084$ & $2,088,781$ \\
\hline 2013 & $4,415,756$ & $3,169,890$ \\
\hline 2014 & $4,231,629$ & $3,318,320$ \\
\hline 2015 & $4,236,506$ & $2,971,903$ \\
\hline 2016 & $4,176,473$ & $2,655,233$ \\
\hline
\end{tabular}

Table 4: Treated and produced water in the desalination plant of Irrigation Community Arco SurMar Menor (2008-2016). Source: authors, data from IC Arco Sur-Mar Menor.

\section{Conclusions}

Propelled by water scarcity and national policy, the Southeast has expanded its desalination infrastructure greatly in the last decade, moving away from water transfers. But is Southeastern Spain too dependent on desalination? Too much dependence on desalinated water creates a "water-energy nexus" in which any disruption in the energy supply would have a direct and negative impact on the water supply (McEvoy and Wilder 2012: 360). In such a situation a failure that interrupts the operation of one or more facilities would affect the whole regional system. Also, if the political or economic conditions change in ways that negatively affect desalination (less support; greater costs), too much use of desalination can leave the water system vulnerable.

Fortunately, there is no total dependence on desalination in the Southeast of Spain, but it does represent an essential source of supply. Multiple water sources supply the Spanish Southeast, including significant flows from the Taibilla River, the Tagus-Segura Transfer, local rivers like the Segura, from groundwater (Guadalentín and Calasparra wells, etc.), reclaimed water, and desalination. In deciding on how to use these different water sources, in what proportion and at what rate, geography, the importance of different uses, the natural 
environment, and technological issues are all taken into consideration. Given this wide diversity of water sources and technologies and modest flows, an increase in desalination has insured minimal water supplies.

Desalination plays a stabilizing role in the Spanish Southeast. Its flows provide a continuous supply in a context of diminishing supply from other sources. In the present moment, when the debate over water sources has polarized and transfers are deeply questioned, desalination stands out as a viable solution. Water security from desalination has supported tourism and and is a supplement that helps agricultural growers avoid "water stress" for high-value crops including fruit trees or vegetables, and to maintain hard-won markets for these products. Recognizing this, the State has agreed to subsidize the price of desalinated water to agriculture in drought situations, reducing it from $€ 0.40-0.60$ (US\$0.44-0.66) $/ \mathrm{m}^{3}$, to no more than $€ 0.15$ (US $\$ 0.17$ ) $/ \mathrm{m}^{3}$.

The economic benefit of desalinated water in arid environments is unquestionable. For example, Abu Dhabi has been transformed into an "oasis" thanks to desalinated water, "overcoming water scarcity and fostering a sense of abundance among citizens" (McDonnell 2014: 227). In Abu Dhabi, the use of this water is rarely questioned, and "many perceive it as a sign of very remarkable development, wealth and economic power" (McDonnell 2014: 227). Large regions of the world with similar characteristics opt for desalination as a "drought-proof" solution (Cooley et al. 2006: 2), and as a less confrontational method than the redistribution of water from rural areas to urban areas (Smith 2009).

Nonetheless, it is necessary to further encourage the diversification and consolidation of water flows to ensure water security, economic stability, social welfare and quality of life. The decision between making water transfers and using desalination is deeply political in Spain, as it is elsewhere (Fustec 2017: 7; March et al. 2014), and in such situations, political commitment to a certain way of provisioning and financing water must be constant and continued over time to achieve efficiency and stability. Energy sources and costs are also prone to variability, especially as Europe responds to climate change by moving toward carbon neutrality. A diverse water source portfolio is the best strategy in uncertain environmental and political-economic contexts.

Desalination involves environmental risks, so it is necessary to take precautions. The location of desalination plants is a primary factor to be taken into account, to avoid fragile ecosystems with sensitive and endangered species, or those important in terms of their productivity or biodiversity. The site of a desalination plant must allow for the dilution and dispersion of the brine, which depends on factors such as marine circulation, currents, tides, depth, and underwater morphology. Areas with strong currents are generally preferred over gulfs and calm waters with few water exchanges (Kämpf and Clarke 2013: 502). The Spanish press and its readership are well aware of the problems that brine can cause to Posidonia seaweed if not discharged correctly.

Finally, it is vital to remind water users that, despite the supply produced by desalination, there is natural scarcity and a need to use water efficiently in dryland environments. Desalination is one way to address water scarcity within the larger question of water supply and demand, and it has pros and cons (Speckhahn and Isgren 2019). Produced water should not be allowed to create a sensation of "hydraulic opulence" (Walsh 2018), because the energy and environmental costs of desalination can be high. All water conservation and saving measures must be developed implemented, such as rainwater harvesting (Warner 2009), and impermeable greenhouse surfaces that collect and channel water back to crops. Once the decision to desalinate is adopted, limits to urban growth and water consumption must be set and enforced (McEvoy and Wilder 2012: 361). In situations of scarcity and controversy such as Southeast Spain, it is crucial to promote citizen awareness of the technical and political realities of desalination.

\section{References}

Arrojo, P. 2000. El Plan Hidrológico Nacional: un desencuentro con la historia. Ecología Política 20: 43-58.

Baltanás, A. 2013. Algunas consideraciones sobre la desalación en España. Revista de Obras Públicas 160: 3538.

Bates, B., Z.W. Kundzewicz, S. Wu and J. Palutikof (eds.). 2008. Climate change and water. Technical Paper of the Intergovernmental Panel on Climate Change. Geneva: IPCC Secretariat. 
Bernabé-Crespo, M.B. and J.Ma Gómez-Espín. 2015. El abastecimiento de agua a Cartagena. Cuadernos geográficos 54(2): 270-297.

Boelens, R., J. Hoogesteger, E. Swyngedouw, J. Vos and P. Wester. 2016. Hydrosocial territories: a political ecology perspective. Water International 41(1): 1-14.

Brite, E.B. 2016. Irrigation in the Khorezm oasis, past and present: a political ecology perspective. Journal of Political Ecology 23: 1-25.

Caldera, A.R. 2017. Cambio y confrontación de proyectos políticos en la gestión del agua en Mexico. In Denzin, C., F. Taboada and R. Pacheco-Vega (eds.). El agua en México. Actores, sectores y paradigmas para una transformación social-ecológica. Mexico: Fundación Friedrich Ebert. Pp. 216-248.

Cavanagh, C.J. and T.A. Benjaminsen. 2017. Political ecology, variegated green economies, and the foreclosure of alternative sustainabilities. Journal of Political Ecology 24: 200-216.

Chowdhury, F., C. Lant and B. Dziegielewski. 2013. A century of water supply expansion for the US cities. Applied Geography 45: 58-76.

Cooley, H., P. Gleick and G. Wolff. 2006. Desalination, with a grain of salt: perspectives from California. Berkeley: Pacific Institute.

Del Moral, L. and N. Hernández-Mora. 2016. Nuevos debates sobre escalas en política de aguas. Estado, cuencas hidrográficas y comunidades autónomas en España. Ciudad y Territorio: Estudios Territoriales 190: 563-583.

Fustec, K. 2017. Qualifier la gestion de l'eau, se positionner par rapport au conflit: les cas de l'usine de dessalement dans la bande de Gaza et du canal entre la mer Rouge et la mer Morte. Développement Durable et Territoires 8(1): 1-21.

García-Rodríguez, J.L., F.J. García-Rodríguez and C. Castilla-Gutiérrez. 2016. Aridity, desalination plants and tourism in the eastern Canary Islands. Island Studies Journal 11(1): 113-130.

Gil-Meseguer, E. 2017. Antecedentes de transvases de agua al Sureste de España como la Conexión NegratínAlmanzora. Cuadernos Geográficos 56(2): 48-71.

Gil-Meseguer, E., M.B. Bernabé-Crespo and J. Ma Gómez-Espín. 2017. Las políticas de trasvases de agua y desalación en España, sus repercusiones en la ordenación del territorio del Sureste. XXV Congreso de la AGE, Madrid. Pp. 2480-2489.

Gil-Meseguer, E. and J.Mª Gómez-Espín. 1993. Galerías con lumbreras en el Sureste de España. Papeles de geografía 19: 125-143.

Gómez-Espín, J.Mª 2004. Aprovechamiento integral del agua en la Rambla de Nogalte (Puerto Lumbreras Murcia). Murcia: Universidad de Murcia.

Gómez-Espín, J.Ma. (ed.). 2017. El Trasvase Tajo - Segura. Propuestas para su continuidad y futuro. Saarbrücken: Editorial Académica Española.

Heck, N., A. Paytan, D.C. Potts and B. Haddad. 2016. Coastal residents' literacy about seawater desalination and its impacts on marine ecosystems in California. Marine Policy 68: 178-186.

Kämpf, J. and B. Clarke. 2013. How robust is the environmental impact assessment proocess in South Australia? Behind the scenes of the Adelaide seawater desalination project. Marine Policy 38: 500-506.

March, H., D. Saurí and A.M. Rico. 2014. The end of scarcity? Water desalination as the new cornucopia for Mediterranean Spain. Journal of Hydrology 519(2): 642-652.

McDonnell, R.A. 2014. Circulations and transformations of energy and water in Abu Dhabi's hydrosocial cycle. Geoforum 57: 225-233.

McDonald, R. I., K. Weber, J. Padowski, M. Flörke, C. Schneider, P.A. Green, T. Gleeson, S. Eckman, B. Lehner, D. Balk, T. Boucher, G. Grill and M. Montgomery. 2014. Water on an urban planet: urbanization and the reach of urban water infrastructure. Global Environmental Change 27: 96-105.

McEvoy, J. and M. Wilder. 2012. Discourse and desalination: potential impacts of proposed climate change adaptation interventions in the Arizona-Sonora border region. Global Environmental Change 22: 353363. 
Montaner, M.E. 1994. Desalación de aguas salobres: análisis de una propuesta de la administración. Papeles de Geografía 20: 211-220.

Palerm, J. and T. Martínez. 2000. Antología sobre pequeño riego. Volumen II. Organizaciones autogestivas. Mexico: Plaza y Valdés / Colegio de Postgraduados.

Radonic, L. and S. Kelly-Richards. 2015. Pipes and praxis: a methodological contribution to the urban political ecology of water. Journal of Political Ecology 22: 389-409.

Rico Amorós, M., V. Panos Callado, J. Olcina Cantos and C. Baños Castiñeira. 1998. Depuración, desalación y reutilización de aguas en España. Oikos-Tau. Barcelona.

Robbins, P. 2012. Political ecology: a critical introduction. Oxford: Wiley-Blackwell.

Ruiz, R. 2017. Conflictos socioambientales en torno al agua en Mexico. In Denzin, C., F. Taboada and R. Pacheco-Vega (eds.). El agua en México. Actores, sectores y paradigmas para una transformación social-ecológica. Mexico: Fundación Friedrich Ebert. Pp. 57-78.

Rutherfurd, I. and B. Finlayson. 2011. Whither Australia: will availability of water constrain the growth of Australia's population? Geographical Research 49(3): 301-316.

Smith, W.J. 2009. Problem-centered vs discipline-centered research for the exploration of sustainability. Journal of Contemporary Water Research and Education 142: 76-82.

Speckhahn, S. and E. Isgren. 2019. The irresistible solution: rationale and risks of extending water limits through desalination in the case of Gotland, Sweden. Journal of Political Ecology 26: 128-149.

Swyngedouw, E. 2004. Globalisation or 'glocalisation'? Networks, territories and rescaling. Cambridge Review of International Affairs 17(1): 25-48.

Swyngedouw, E. 2013. Into the sea: desalination as hydro-social fix in Spain. Annals of the Association of American Geographers 103(2): 261-270.

Swyngedouw, E. 2015. Liquid power: contested hydro-modernities in twentieth-century Spain. Cambridge: MIT Press.

Torres, M. 1994. La desalación de agua en España. Panorama actual y futuro. Seminario de la Universidad Internacional Menéndez Pelayo de Santander "Recursos hidrogeológicos y recursos hidráulicos no convencionales". 30 agosto-3 septiembre 1993. Ministerio de Obras Públicas, Transportes y Medio Ambiente.

Vera, J.F. 2006. Agua y modelo de desarrollo turístico: la necesidad de nuevos criterios para la gestión de los recursos. Boletín de la AGE 42: 155-178.

Walsh, C. 2011. Managing urban water demand in neoliberal Northern Mexico. Human Organization 70(1): 54-62.

Walsh, C. 2018. Virtuous waters: mineral springs, bathing, and infrastructure in Mexico. Oakland: University of California Press.

Warner, R. 2009. Secular regime shifts, global warming and Sydney's water supply. Geographical Research 47(3): 227-241.

Ženko, M. and S. Uležić 2019. The unequal vulnerability of Kurdish and Azeri minorities in the case of the degradation of Lake Urmia, Iran. Journal of Political Ecology 26: 167-183.

Ziolkowska, J.R. and R. Reyes. 2016. Geospatial analysis of desalination on the US: an interactive tool for socio-economic evaluations and decision support. Applied Geography 71: 115-122. 